\title{
The “Competent Literary” Teacher: The New Perspectives of Initial Teacher Training
}

\author{
Antonella Nuzzaci \\ University of L'Aquila, \\ L'Aquila, Italy
}

\author{
Stefania Nirchi \\ National Agency for the Evaluation \\ of Universities and Research \\ Institutes, Rome, Italy
}

\author{
Luca Luciani \\ University of L’Aquila, \\ L'Aquila, Italy
}

\begin{abstract}
The aim of the paper is to describe the literary competence of teachers as a dimension of the knowledge for the teaching, which can be extended to all aspects of the professional teacher transformation. Among the various knowledge, competences, and dispositions the shape its legacy, the literary competence becomes the main turning point between pedagogical knowledge and specialized knowledge, between core and characterizing disciplines. The literary competence lives in the intersection between different kinds of competence (linguistic competence, communication competence, reading competence, writing competences, interpretive competence, discursive competence, cultural competence, cross-cultural competence, pragmatic and strategic competence and social competence). The approach offers a framework for pedagogy of the literary competence in the teacher training as substantial experience and expertise able to increase the professional repertoire of teachers in training fields. This paper provides food for thought for enrichment and enhancement of the literary competence and its use in teaching.
\end{abstract}

Keywords: literary competence, higher education, initial teacher training, teaching-learning processes

\section{Introduction}

The literary competence has become over the time a key term in the discourse of literary education, even if its meaning is not clear yet. If literary education often appears as a generic expression, even more generic is literary competence. In Italy several scholars have been engaged in studying said aspects as demonstrated by the recent conference organized by the didactic section of Associazione degli italianisti (Association of Italianists) held on 13th March 2013 at Università di Padova (University of Padua) and the related debate started before (Tonelli, 2013), even if the first literary researcher that underlined its importance was Coenen (1992), who tried to define and systematize such a competence by considering the competent literary reader as someone able to talk and communicate literature, as well as master roles and rules of literary discourse and knowledge. Nevertheless, the expression "literary competence" is known as coming from the literary theories of Culler (1975) and Schmidt (1982), who used it by analogy to Noam Chomsky’s (1965) linguistic competence and in various meanings in the different countries in relation to purposes of teaching literature (Soetaert, 1992; Soetaert \& Mottart, 2003). At the end of the eighties, in programmatic documents and in

Nuzzaci Antonella, Associate Professor of Experimental Pedagogy, Department of Human Studies, University of L'Aquila.

Stefania Nirchi, Expert for the quality of the teaching university at National Agency for the Evaluation of Universities and Research Institutes (ANVUR).

Luca Luciani, Assistant Professor, Department of Human Studies, University of L’Aquila. 
professional magazines for teaching literature, the meaning of "literary competence" seems to fall into the fog after its frequent use in a wide range of contexts ending up to make the term unusable and unintelligible (Ibsch, Schram, \& Steen, 1991). Coenen (1992) thinks that this represents a reason to better define the teaching of literature that cannot be confused with that of "programme of literature”. De Groot and Di Medendorp (1986) introduced the "concept of semantic analysis" that induced them to define the literarily competent reader able to communicate "with and on" literature and at least able to build the coherence of a text, although the content of communication may hugely vary. This entails the construction of a coherence aiming at improving the understanding between different literary texts, with reference to the world (the society and the personal world of the author), to the personal opinion on the literary work and that of other readers. The attitude of the literarily competent reader is characterized by a will to invest in reading and to be open-minded in relation to perspectives and reference frameworks (Coenen, 1992, p. 73) that turns into original ways of thinking. Over the last decades, a series of instruments has been developed for texts analysis, that, from philology to structuralism up to semiotics, have assumed an increasing importance in teaching, mainly aiming at developing in the reader the capacity of understanding and interpretation of literary texts in relation to reference contexts ("given" and "located"), temporality and spatiality and, in an advanced phase, capacity of producing them. The acquisition of a literary and critical competence comes from the educational importance for some intrinsic qualities of the literary language and the narrative practices that were matter of interest by scholars of several disciplines, but analysed in depth by researchers of the sector such as Remo Ceserani (2010), defining such a situation "contradictory and almost paradoxical" since if, on the one side, literature and literary criticism have no longer the centrality and prestige enjoyed over the centuries in western schools and culture, on the other side, those dealing with branches of knowledge other than the literary one, in a twist of linguistic and cultural loan words and calques, are more and more interested in narrative practices and language. This as evidence of a form of unexpected and tenacious persistence ranging between the tendency of literature to lose its traditional prestigious position within culture and an increasing interest in literature that sees the emergence of the requirement to equip the readers with an interpretive approach to texts requiring an activity of complicated cultural mediation in order to allow them to interpret carefully and correctly a literary text, understand it in depth by analysing its signified elements, signifiers and the connections between them. Furthermore, the readers while reading the text enter into relation with all of this by using their experiences and ideas, as well as their own interpretive and reflective structure. A form of individual awareness that requires, for reception and elaboration of information, appropriate reading instruments, aiming at the promotion of a literary fruition not exclusively focused on the linguistic education and varieties of languages of the literary language, but also on the capacity to place the texts in their historical context, in cultural and literary history etc. achieving the result to make the readers express a critical opinion (attention to the work in its context of production) and a personal opinion (opinion of the reader on the work) in terms of responsibility and cognitive and interpretative autonomy. The literary mastery, as a combination of intellectual and instrumental skills, attitudes, beliefs etc., allowing to activate processes of reception and production of literary texts of various kinds, as well as activate evaluation, elaboration, production and communication skills, of literature, orchestrating resources and competences (cognitive, affective etc.) necessary to acknowledge the need for literary fruition and to locate, read, evaluate, apply, and create literature in a given cultural and social context, feeds the critical thinking and the interpretation techniques strengthening the interpretive repertoires of individuals and communities. Within the wider and more complex debate around the role of literature (suffice to think to recent initiatives, such as the 
Day specifically dedicated to "Letteratura per la scuola, competenze per la vita" (Literary for school, competences for life) of 29th October 2014 organized by the Ministry of Education, Directorate for School Systems, in cooperation with Associazione degli Italianisti-ADI-and 12 universities within the project "CompIta" focused on competences in speaking Italian and its role), the concept of literary competence in terms of analysis of the literary text, that is mainly positioned in Italy during the years of high school, makes hope that the students achieve to possess a corpus of characteristics allowing them to express themselves on particular points of view and kinds of texts, and to make this in a certain particular language, in a specific context, in specific situations; they are factors that shall be assessed through specific, valid, and reliable instruments evaluated according to particular criteria reflecting their performance at a particular level (Coenen 1992, p. 71). These elements offer in this way clues to identify the various levels of such a competence. But the main issue lies in the fact that it is not clear whether or not some of the combinations of these elements correspond to the levels of literary competence. How can we say whether or not upper secondary school students in the interaction with a text have the literary competence and at which level and with which kinds of texts? How can the students during their school experience achieve the literary competence? How do they build their literary knowledge over the time? Which acquisitions should be mastered in order to generate such a competence? Which are the responsibilities (Brumfit \& Carter, 1986) that can be attributed to teachers in their role of guide of each student, since the nursery school, towards the development of a literary competence bringing them over the time to pay attention to types of styles, forms, symbolizations? Usually in the primary school the learning of literature is exclusively promoted depending on the language and twine itself inextricably with the latter that is taught with reference to the development of four essential competences (reading, listening, talking, and writing), it is likewise true that it should not be considered a mere instrument to develop such competences. Literature expresses itself through the language and presents itself in its most subtle hues of meaning and ambiguities. From this point of view "language" and "literature" live of mutual support (Bassnett \& Grundy, 1993). If we think in terms of competence in literature (identifying information, completing and reflecting, reflecting and evaluating, OECD-PISA, 2009), writing, talking, listening represent concrete examples showing how often in the educational area the objectives of language and literature are often connected and integrated. Hence, if it is true that in the primary school, context where the first education of the reader occurs, the efficient readers are built (Cardarello, 1995; Cardarello, 1997; Cardarello \& Chiantera, 1989; Lumbelli, 1988), readers that should master specific skills and strategies allowing them to turn the words on the page of a literary work into literary meanings and master some conventions on how a text should be read and understood, it is likewise true that the literary competence entails a set of competences and sub-competences that the teacher should possess and allow the teacher to improve the writing of teaching and planning of his lessons, as well as create the conditions to ensure his students the full achievement of those skills, attitudes, and independent processes that represent "the conventional precursors of reading and writing", or rather, in particular to:

(1) make know the rules of print, emergent reading, awareness and phonological memory, syntactic awareness, pre-reading and emergent writing, lexicon and reasons why reading (Cisotto, 2006; Cisotto, Gruppo RDL Infanzia, 2009) at a different degree of school and on the basis of an educational continuity;

(2) guide them in facing an appropriate reading in various literary texts (rhetorical figures, such as metaphor, similarity, personification, hyperbole, epithet, apostrophe, oxymoron, metonymy etc.; narrative and poetical expedients such as plot, story, character, point of view, preparation, irony, satire, paradox, assonance, alliteration, rhyme, rhythm etc.; specific characteristics of the text such as topic, style, etc.; literary trends such 
as Classicism, Romanticism, Realism, Modernism etc.; literary forms such as diary, epigram, heroic poem, lyric, ode, sonnet etc.; literary genres such as novel, tale, poetry etc.);

(3) create the favourable disposition to use "literary skills" to interpret and elaborate texts.

The literary competence appears today as a process of activation of various "discursive forms" that opens a passage through the violent ambivalences characterizing our era and allowing to identify/create deviations, intervals, interstitial spaces within the flows of communication. The practice of the analysis of the text explains at best the literary posture to the extent that focuses the exercise of the competence on what escapes from the same competence (Citton, 2011), but the real problem is the interpretation that represents the main concern of many talking about concepts such as opening and restriction between text and reader (Citton, 2011), actually ending up to define and limit the essential negotiation between text and reader. Between author and text, the literature of competences chooses to move the spotlights on the reader: the reader that makes use of and learns "with, through and the" literary knowledge. The literary competence benefits the capacity to acknowledge, decode and produce a personal feedback to the text; this entails the assumption and use of a metalanguage and a metalinguistic competence that shall be compared to the whole process of learning and teaching and progressive appropriation of the language that sees the awareness of the language acts as artefact comprising syntactic units (sounds, words and sentences) and semantic structures and creates a connection between linguistic competence and literary competence and of them with those of the similar families. Such an awareness has to do with that "law of comprehensibility" (Lumbelli \& Salvadori, 1977) that allows symbolizing and perfecting the thinking and going beyond the text (Genovesi, 1993) and that is often far from what is actually learnt at school, which should in its complete cycle working for building in students higher-order skills too. Nevertheless, it is just a specific literary terminology providing the students with instruments to identify, interpret, and appreciate the value of peculiar characteristics of a literary text and express personal opinions on it, to make familiar and more pragmatic the learning of literature, if they really master appropriately the language. The necessity of a change of perspective in the definition of literary competence and its acquisition methods from the nursery school to the university entails both declension of the prerequisites at various levels and adoption of indicators and parameters aiming at describing their level of final mastery at high school level, which content of its communication ranges and is connoted by a clear will of the reader to invest in reading with an open mind to change and a reflective capacity on what is reading; and this depends on the basics and acquisitions acting as prerequisites with respect to the following cycle and the experiential progress that is implemented during the educational process. It is known that the "pleasure of reading is not a discovery made in adult age" (Livolsi, 1986, p. 51) and that, during the educational path, in order to be able to read, understand and interpret literary texts, several difficulties shall be faced and important "cognitive fords" shall be crossed to realize that process of acquisition allowing to turn the beginner reader into "competent consumer of literary texts", namely, able to understand how the authors use some literary conventions to communicate their intentions and to formulate these communication conventions. The future non-disciplinary teachers, or rather not the future teachers of Italian or foreign literature, but the future teachers of nursery and primary schools, on whom this contribute is focused, shall be aware of all of this.

In the same way as there are rules and principles in the spoken discourse, literature, including as communication means, is framed by expectations and standards forming an important element of communication between teacher and student, between text and reader, which assume a key role in building the capacity to teach. In this sense, the teacher of the nursery and primary schools in the initial education shall be 
allowed to understand that the literary knowledge may perform a synergic role in the capacity to help the students, whom they will take care of, to learn essential prerequisites to build the literary competence, by identifying the most appropriate strategies to face the literature of a text and improving in this way the phonological, pragmatic awareness, etc. and how becoming competent readers (Isenberg, 1990) gaining progressively a positive attitude towards the reading of literary texts.

\section{Text and Reader: Learning to Teach With Literature}

Teaching strategies to read the literary text in university classes, where the literature teachings are performed, assumes a crucial role in developing a wise literary competence, for the students future teachers are readers called to build meanings as of any genre of text, whether or not literary, which interpretation is set and limited by the same authors (Paran, 1998), their unsuitable knowledge at any level, or rather at different degrees of competence can be attribute to a lack of cultural preparation and a bad mastery of the basic interpretive instruments, since usages of literary texts are tightly connected to sophisticated uses of language, such as the figurative one, which the codes and symbolic repertoires of culture are linked to, or rather components, other alphabets, essential conditions, representations, elements, hence the cultural heritages of individuals and communities they belong to. In this logic, teaching literature in the Degree Programmes of Science of Primary Education represents much more than a way to steer students to understand the importance of literature, but becomes an educational instrument to welcome and interpret the cultural characteristics of a certain community. Domain of educational transversality, literature becomes in this meaning a crucial component of the "profession" of teacher of nursery and primary schools both at the level of self-construction (personal) and at the professional level in a path of construction of meanings that always calls into question vision of oneself and of the world. A literary text is considered, irrespective of its use in a lesson of language or history, an essential support to help every student to circumscribe specific visions of the world, where the role of the teacher of nursery and primary schools is the one to mediate and build an interface between every reader and genre of text examined, to help the student to face the various "textual problems" met in comprehension and to encourage to acquire awareness about classification and cataloguing of information within specific cognitive and interpretive universes.

The teachers may turn to draw the attention from time to time on aspects of different order that may concern texts, for their goal is to put the bases in order that in their future educational path the students can catch both intertextuality (between data and text) and extratextuality (or rather place the text in its historical-cultural context placing the reader between text and knowledge of the readers of the world), elaborate a gradual reduction of a text through various phases of refinement, demonstrating how in this way every element of synthesis allows the logical recovery of information comprised therein. The initial education of teachers of nursery and primary schools should deal with the problem of teaching literature to make learn how to use it in an educational context, namely in a phase where the university teacher may come back to decide to share in class with the future "teacher" the "competence of text". Now, a data analysis can be carried out, as well as provide the students with basic information or concepts that they have not acquired or understood yet etc. allowing the students to become more autonomous readers, and thus more qualified, by elaborating more efficaciously the information provided by the teacher, information that shall still be organized in their "interpretive encyclopaedia", namely in a framework of understanding whereon anchor the new knowledge through imitative, heuristic, or creative strategies. Of course, it is also possible and useful as an occasional and alternative exercise, starting with the presentation of a critical study of a literary work allowing the university students to work backwards from the critic's generalizations to 
the specific evidence in the text. This teaches them also how to acquire critical sense and to be bearers of the understanding of meanings. The use of literary competence, combined with that of literature in contexts of university education, makes challenging the behaviour of the university teacher within the educational context of teaching literature, where borders and definitions tend to make fluid also the understanding of other disciplines (such as the example concerning the understanding of a math problem). This is that curricular logic including the approach for competences guiding the acquisition of the linguistic domain towards the development of the literary awareness and action of decoding, based on educational processes and procedures able to make the process of education proactive and significant, making possible the understanding and critical interpretation of complicated texts to make later licit their didactic transposition. Nevertheless, over the time the various interpretations of the concept of "literary competence" have really affected the way to teach and evaluate it (such as the ways to introduce texts and verify if the learners have understood the text, set the interpretation on a merely aesthetic vision of literature, ask questions on action, plot, and characters of the text, read only the summary of a text to understand its plot and so on), in academic contexts, above all when this has concerned the relationship between experts of different sectors and education of teachers (linguists, literati, philologists, pedagogists etc.). This, from time to time, has affected often confused educational readings and proposals, that created problems in the construction of the profile of future teachers, who, in turn, gave place to cultural interventions and proposals in educational contexts that did not always fit with the students' skills, above all those of nursery and primary schools, but also those of lower and upper secondary school, with ill-fated effects on readers and their reason and favourable disposition to read literary texts. The absence of a clear sense and value of literature, along with the aesthetic and creative aspect, emphasized by many parties as the intrinsic value of the literary text, has sometimes promoted, in the learning contexts, fanciful attitudes and free approaches to literature, that instead of encouraging behaviours of literary mastery and use of the language, activating a teaching based on specific and higher-order skills, have ended up to promote behaviours of distance from or refusal of literature. With the promotion of the literary knowledge, hence, the expectations are that the future teachers can acquire solid scientific approaches of methodological area allowing them to provide their future students with the instruments for an individual elaboration, also connected to the request of identity of the reader helping to emphasize over the time the self-awareness for a progressive success in acquiring and understanding the literary and poetical knowledge, that requires favourable disposition to reading and it mostly depends on the self-esteem of the student as a reader. The result of such a point of view is that the attitude towards the literary text shall be built and cultivated as of the texts but also from the capacity to choose texts. This means that the "competent literary" teachers in the continuity of the various school grades should progressively teach to the "students readers" to appreciate not only linearities, mixtures or originality of texts, but also ambiguities of fiction, drama, poetry, tale, novel etc. if we want that the literary competence does not lie only on the effort to extract meanings from a text. The beginner readers are those that sometimes cannot understand metaphorical or symbolic uses of words and so they have no literary competence meant as mastery of roles and standards of the literary discourse. The teachers of the nursery and primary schools shall understand that behind such capacities that will be developed later there is their actions, the basis of an educational, effective, and qualitatively significant action to make possible what would happen elsewhere, at another school level and grade. Without laying the essential foundations in order that all of this occurs, without building the framework whereon the literary competence is based, it will be impossible in teaching-learning contexts to achieve the deepest layers of the text activating affective, cognitive, and positive behaviours of the students towards literature. This means that the literary competence loses its meaning if not 
considered in prospect, as a dimension needed to anchor over the time deeply and personally the meanings to the interpretive repertoires of students. In the pedagogical language, the future, competent, literary teachers shall be aware of the existence of symbolic codes to interpret and use them educationally. The literary texts, as polysemic, have at least two interpretive levels, literal or denotative and connotative, metonymic and metaphorical (Jakobson, 1988). Non-sophisticated readers can read texts just by using the literal level, assuming its nominal value (this is tangible above all in narrative with non-mimetic explicit structure, for instance in novels that characterize a travel in an imaginary world), with evident problems in the capacity of teaching. The understanding of symbolic meanings assumes a high degree of competence of codes by the competent literary teacher, able to go beyond the interpretation as such to turn towards other interpretations. In this sense the challenge of the initial education of teachers is that to look at a poetry and literature in class as a place not only for the creation of competences of the sector but also of original competences and knowledge in the learner future teacher, in order that the process of reading literature turns into a significant experience to give place to those processes of symbolization and conversion of the reader's mind, helping to complete the process of construction of symbolic repertoires of culture, essential condition to be able to teach, educationally transpose anything learnt from specific disciplinary sectors concerned (linguistic, literature etc.) and perceive an organization of culture able to make accessible for everyone a heritage that too often tends to be the privilege of few, rather than giving prescriptions and raising barriers to understanding that induce to distance from the text, to those subtle mechanisms of exclusion that pass through culture and teaching (Bourdieu, 1988) and that concerns both teacher and learner. In this direction, Pierre Bourdieu shares with many scholars the belief of the importance of the subjective and objective experience through practices that could have a discursive goal in relation to causes and effects of the structural signification of the human activity (Usher \& Edwards, 1994, p. 18) and the concern for the language either in its constitutive effects or its textual characteristics in both main aspects concerning the study, understanding and construction of written texts and systematized meaning translated into "practice and human action". The literary meaning is a personal experience in the meaning that the future teacher, student being trained, will experience a text in a difference way than another reader, but will share with others some main nucleuses and then will become able to operate on it and transfer it to teaching-learning contexts when will be in class with children. In this way, reading literature becomes educationally a significant experience and a way to learn but also to teach. The university student in the pre-service phase is a "special" reader needing to look at "substance" of literary texts and this entails the necessity to acquire an appropriate use of the educational communication and language functioning entailing an act of reading and an experience of literature and the assumption of a positive attitude to its fruition as well as a centering on its nature. Usually teachers, including in-service teachers, ask to the research to indicate appropriate methods that are viable, or rather directly applicable or operating, and that help to identify practical methods to teach in class; often they are erected in favour of an operating fusion between theory and method to achieve practical purposes concerning the "making education with texts", but it is known as no approach is able to explain the complexity of learning to teach literature and to generate appropriate strategies that may solve the problems of teachers in class if the point of view is not changed. In this regard, the way could be the one traced by John Dewey (1916), or rather direct oneself towards any model of teaching that induces the student to sail over the subtle ice covering the real problems and overturning the correct method to educate mind, aiming at a "deep" learning for it is the depth with which a problem is perceived to determine the quality of thinking arising from it. In this way, it is pursued an education aiming at building behaviours, styles, conducts, and attitudes, aiming at 
making the future teachers of nursery and primary schools responsible to increase their awareness and role of competent literary readers without resorting to absolutizing and unilateral methods that cannot be able to fulfil the requirements of every student that will meet and solve each peculiar difficulty. The professional habitus of the competent literary teacher is connoted by an educational action aiming at building in students a motivated, open and internalized learning aimed at understanding. In its operating dimension, step-by-step, the education of literature offers a quick, theoretical, and methodological approach for teaching allowing the future teachers to move their attention from text to reader to increase the knowledge through literature and expand the "readers' mind" instead of anchoring them to a collection of events, facts, phenomena; an educational process providing for a profitable effort to make the new young literary competent readers to grow within an educational-institutional framework making them active literate citizens. It could be affirmed that such an adaptation is not only possible but also desirable in the light of a university education that, in the literary area, pursues as purpose the development of a future teacher able to activate a teaching aiming at feeding a stable and lasting reason in the students, encouraging their personal participation and helping to create important connections and cross references between learning carried out in and out of the school; the initial education of teachers in the literary field may favourably influence the profile of the students future teachers and their capacity to read and appreciate critically a literary text, only if it will be able to provide means and instruments to acquire progressively suitable knowledge and competences to turn them, step by step, from literary novices into literary advanced beginners, from competent academics into educational transposers of the literary knowledge, in order that, in their capacity of expert of education, their action will become essential to accompany the students towards the achievement of the goals set and the school success, contributing in a significant way to their emotional (Lazar, 1993, p. 19) as well as cognitive enrichment.

\section{Development of Literary Competence in the Initial Education of Teachers of Nursery and Primary Schools}

Teaching literature strategies in the classes of literature plays a key role in the development of the literary competence (Brumfit \& Carter, 1986). An increasing number of studies has demonstrated that highly qualified and effective teachers have a positive effect on the learning of students (Darling-Hammond \& Youngs, 2002; Haycock, 1998) and if we want to assure a qualitatively substantial teaching-learning process every student needs a highly qualified teacher able to effectively meet their requirements (Margiotta, 1999). This means that the professional profile of every professionalism of teaching should be reviewed and strengthened and the efficacy and academic and pedagogical quality of the initial education of teachers should be re-examined, coherent systems and appropriate resources for recruitment, selection, inducement and professional development of the teaching staff on the basis of clearly defined competences necessary in each stage of teachers' career should be introduced (European Commission, 2013). Hence we witness to the appearance of an original "literacy epistemology" that look to the teaching as a complex multimodal process working through multiple channels and plural-sign codes (see Figure 1), makes it possible to build kills kits every more suitable to feed people in the exercise of active citizenship (Nuzzaci, 2012a, p. 13). 


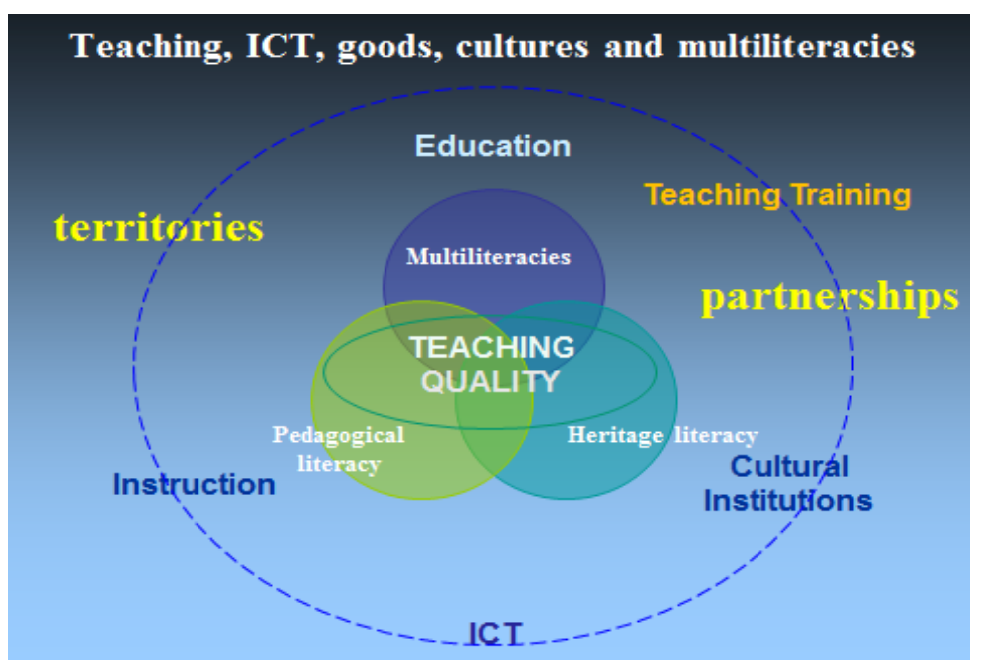

Figure 1. Teaching, ICT, goods, cultures and multiliteracies (Nuzzaci, A., ICT, teaching and multiliteracies, 2014, L’Aquila, unpublished conference paper, L’Aquila, 2014).

The unsuitable preparation of teachers to face the challenge of the 21st century has been faced in Italy by the law 249 of 2010 that paid particular attention to the initial stage of the educational process of teachers of nursery and primary schools, defining the educational path, enhancing and extending the repertoire of competences and strengthening the cultural profile of teachers by structuring a new single-cycle five-year university curriculum and path. The literary knowledge as part of the teachers' curriculum in the university education becomes the starting point of teaching literature as instrument of cultural literacy, aesthetic awareness, social awareness, and personal development concerning specific goals in terms of contents and teaching-learning processes. The term "literary competence" has provided the literary education with a status in the discussion about the position of literature within the curriculum becoming a key element. Today the term has shown to be explanatory enough, above all if considered in the meaning given by Fish (1980), namely a capacity developed from experiences carried out in an "interpretive community". Usually teachers of literature in educating teachers are often defined only in terms of "disciplinary contents" or parameters for selection linked to specific readings. In this context, the description made here try to understand also the educational aspects in relation to activities of teaching and learning. This dimension is significant because of leading to considering the importance of literature not only at national but also at international European level through the concept of "literary competence", which prerequisites, at various level, can be identified and evaluated. Among the various knowledge, competences, and dispositions the shape its legacy, the literary competence becomes the main turning point between pedagogical knowledge and specialized knowledge, between core and characterizing disciplines. The literary competence lives in the intersection between different kinds of competence:

(1) Linguistic competence;

(2) Communication competence;

(3) Reading competence;

(4) Writing competences;

(5) Interpretive competence;

(6) Discursive competence;

(7) Cultural competence; 
(8) Cross-cultural competence;

(9) Pragmatic and strategic competence;

(10) Social competence.

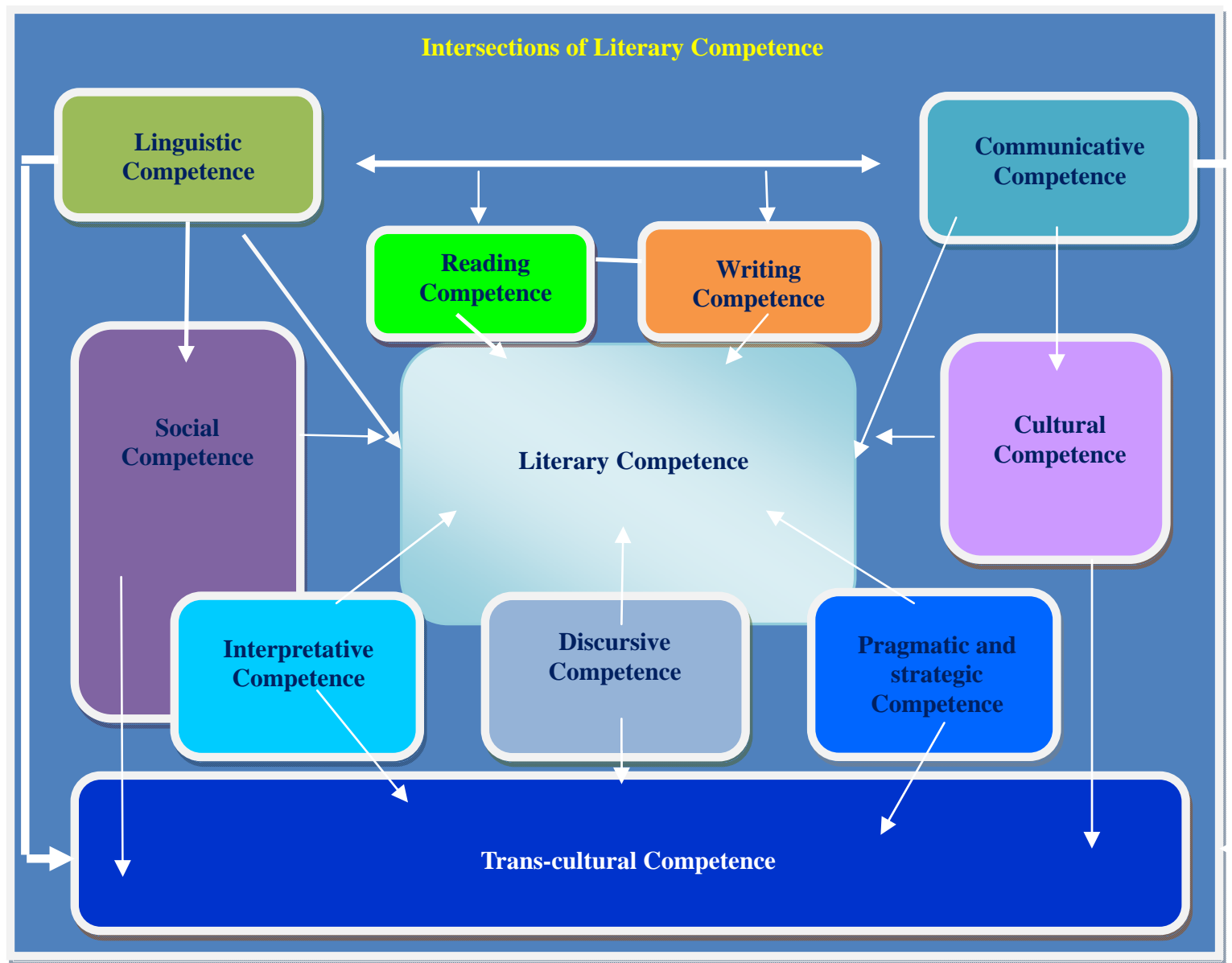

Figure 2. Intersections and literary competence (Nuzzaci, A., Competences, multiliteracies and teaching, 2014, L’Aquila, unpublished conference paper, L’Aquila, 2014).

The model of ten synergically interacting competences tries to answer the basic concern on what using literature in class implies, which does not mean focusing on the "literary nature of texts" (Maley, 1989a, p. 10), but, conversely, improving educational practices in using literature to enhance the quality of teaching supporting both social awareness and linguistic competence, both cultural and communication awareness. In this interpretive key, the literary competence plays a central role in the literacy process of teachers in the initial stage, first of all for the distinctive traits of the discipline as subject of the university knowledge (contemporary and Italian language and literature are taught), but also as instrument to learn other disciplines (understand an order, carry out a demonstration etc.). Hence, it intervenes at two levels of teaching, expressing values built in a wide sense on ideologies, entailing a university teacher (specialist of the sector) and student (future teacher) exchange in the complicated field of beliefs and opinions but intervening in the construction of the cultural world of learning, of construction of teaching, of the personal history of student and teacher and of the professional culture of school and its values. The students future teachers write and re-write, listen to their own and other's word, read in a loud voice, reshape their efforts to make words significant. Literature has no rivals 
in its power to create natural repetition, consideration on language and its functioning. The wide range of genres, accepted as literature, extends its potential influence in classes going beyond the teaching of Italian and school. The use of literary texts in class was widely discussed by a specific and wide literature (Maley \& Duff, 1989; Carter, Walker, \& Brumfit, 1989; Widdowson, 1990; Kramsch, 1993; Lazar, 1993; Carter \& McRae, 1996; Edmondson, 1997) and some scholars (Gilroy \& Parkinson, 1997; Belcher \& Hirvela, 2000; Yang, 2001; Vandrick, 2003; Kim, 2004; Sánchez, 2008; Parkinson \& Reid, 2000, pp. 9-11) mainly support the idea that the role of literature is to provide an excellent model for a "good writing", demanded by educational strategies that leverage on "vicarious” processes (Reuchlin, 1978; 1999; Bertoz, 2015). This is a non-trivial and challenging task also helping to assimilate the rhythms of a language, simplifying the education to a special sensibility. Many genuine characteristics of the written language, such as education and function of sentences, variety of possible structures and different ways to connect ideas are presented at different levels of difficulties (Collie \& Slater, 1987, p. 5), but the important thing in university contexts that take care of educating teachers of nursery and primary schools is the one to ask to university students to explore the literary language and not neglecting its educational viability, not limiting to encourage consideration on standards ruling the use of language (Lazar, 1993, p. 18) and literature. The students shall be encouraged to become familiar with different uses and linguistic and literary forms for an appropriate specialized and educational development of competence and an effective literary communication. In this way, the richness and variety of language can be appreciated and we can become more sensitive to its characteristics. The literary culture as a total enrichment of the set of competences of the teacher carries within the culture of teaching other cultures (local, national, international, and cross-national) and allows cultivating a culture of sectorial educational literature allowing the students future teachers to understand and appreciate cultures and ideologies other than their own, in time and space, and being able to perceive traditions of thinking, feeling and textual and art forms within the literary heritages of given cultures (Carter \& Long, 1991, p. 2). Thus, the future teachers learn progressively to make use of the literary knowledge, that includes countless potentialities, to learn to teach achieving different forms of mastery and learning to look at the world through someone else's eyes, observing the human values, different types of life, discovering other educational and didactic ways and styles in very different societies and cultures, entering into relationship with different codes according to formulating messages with evident increases of signification amplifying the possibilities of the educational action, enlarging its boundaries in terms of perception of new relationships, new visions, new points of view and knowledge of the social sphere, political, historical, cultural, and educational events organized in a certain society. Through literature, the future teachers can examine in depth their cultural understanding of educational facts, events, and phenomena, for the literary texts mark a specific methodological gap compared to reality, even if they often touch common topics and values ranging from individual and personal dimensions to collective and social issues, such as death, love, pollution, ethnic conflicts etc. In this key, the genres, conventions, stylistic expedients and portraits (poetry with its rhythms, rhymes, figurative uses, etc.; prose with its tales, novels, plots, crisis, conflicts and solutions etc.) become necessary elements to be acquired as an experience of mother tongue (Maley \& Duff, 1989, p. 8) from which move to go towards other languages and cultures (learning of L2, cross-cultural skills etc.). That is why, literature becomes the means to understand the possible varieties of matters, languages, topics, and contexts concerning literary texts as "authentic texts, real incontext languages, which we can answer directly” (Brumfit \& Carter, 1986, p. 15). This quality seems to make literature a precious instrument to teach in many contexts and cultures, allowing the university students to understand and appreciate other cultures and ideologies and provide those that 
take care of education of teachers with the possibility to identify methods and forms to be better ready to meet the requirements of every university student (Causton-Theoharis, Theoharis, \& Trezek, 2008). The university reader, future teacher, seems to that "ideal reader" mentioned by Umberto Eco (1979, p. 52), namely who helps to correctly update all the semantic structures of a text and that during the education helps the "empirical" or "real" reader to use it for various purposes, assuming the role to fill the recipient's gaps. Then there is no doubt that the use of literature can be considered in a university context of teachers' education, as concrete possibility to make "work texts" to generate an educational competence of area being able, with appropriate cultural proposals, to improve the literary competence of the university student and fill specific gaps of acquisition. Nonetheless, the gaps keep existing when we think about the various intersections of the literary competence with other kinds of competence, such as that of writing of teaching (Calkins, 1994). Among the various knowledge, competences, and dispositions shaping its legacy, the literary competence becomes the main turning point between pedagogical knowledge and specialized knowledge, between core and characterizing disciplines, that joins vertically the teaching (nursery, primary, lower secondary school etc.) with and through literature. Therefore, there is the necessity to lead studies of research that contribute to understanding which corpus of knowledge the teachers of nursery, primary and lower secondary school need, to make appropriate decisions during those processes of planning and programming education aiming at building the literary competence, for the basic training of the teacher affects decisions and choices of the educational approaches to be used (Lee \& Hemer-Patnode, 2010). It is worthwhile reasoning on these aspects and how knowledge, skills, dispositions in this sector affect the educational planning and the decision-making processes and examining and describing how the latter intervene to assure the school success of students, even keep being awareness that what teachers think, decide, and realize during the process of planning education about the literary competence has a significant effect on learners and on the identification of the necessary prerequisites to pursue it, at a different level, and that need to be accurately identified and evaluated.

In Italy this aspect has assumed particular importance as of the definition of the new curricular path of Science of Primary Education of New System, single-cycle five-year university course of study started and activated for the first time in 2011 and that sees (see Figure 2) the professional learning of teacher as included in a continuum starting from the initial education of teachers, carrying on through the stage of inducement and for all the rest of their career. In this context, the literary competence becomes central and concerns the possibility to achieve a wide consensus on descriptions of competences that extend to various levels of teachers' competence. The research suggests that the development of the literary competence of teachers is rather slow and entails in teaching a reflective logic, a proactive practice and high quality feedbacks. As a whole, the nature mainly tacit of the practical thinking of teachers entails complicated cognitive processes to develop the professional knowledge, in line with everything indicated by the European Commission (2013); hence, as regards the key aspects of the process of professionalization, the literary competence acts:

(1) on constant consideration in relation to update and progress of practices;

(2) on cooperation with the professional community (OECD, 2009);

(3) on belonging and construction of the professional world.

The main characteristics of expert teachers include:

(1) routineness, namely the development of models of action and repertoires of teaching;

(2) specific domain and expertise in acknowledging models (recurring situations) in the complexity of life in class; 
(3) sensitivity for social requirements and dynamics of class;

(4) problems of understanding;

(5) flexibility and improvisation;

(6) critical examination of one's professional practice (at school and in national contexts, as well as in professional dialogues) (European Commission, 2011).

Two requisites are essential in the preparation of quality teachers:

(1) the capacity to evaluate systematically one's base of knowledges and professional practices, on the basis of a wide range of criteria coming from practice, theory and research;

(2) critical and reactive attitudes to innovation and professional improvement (Hagger \& McIntyre, 2006).

Hence, if a key role is performed by self-evaluation of teachers, reflection on their job and professionalization, then the construction of the literary competence follows this direction, that of curricular strengthening to develop the necessary competences. A culture of the literary competence should be a stable component of the initial education of teachers at any level, even if in an articulated way for the various levels and curricular programmes. It is clear that the presence of purposes of education will allow and require a higher extension and depth of development with respect to the grade of school and type of professionalism teacher concerned, given the presence of schools stages with different purposes and curricula. Then there is the problem of the standards with respect to real curricula and the problem of how projecting each standard on the specific disciplines concerned and disciplinary programmes. In system such as the Italian one, such standards should be taken into consideration by a rather wide variety of specialized, whether or not specific, disciplines, above all if we refer to the nursery and primary schools, whereon the "conditions" for the development of the literary competence and of a culture of language and Italian literature, included in the programmes of other school stages, are based. In particular, the literary competence in the professional development of teachers of nursery and primary schools helps to support the development of a community of knowledge around the knowledge and languages and the practice of key competences of teachers that are behind the educational change and requiring a critical mass of teachers trained on aspects, topics, models and approaches joining the solid pedagogical, methodological and educational culture with the sectorial educational culture, fostering progressively a process of curricular innovation and disciplinary contamination promoted by the national indications expressed as competences. The lacking presence of such a competence prevents the development of a capacity of analysis that is not just an instrument to improve the oral and writing practice of the Italian language, but can also persuade to have a more direct and, sometimes, more subtle perception of reality and teaching. In contexts of initial education where the role of literature, in terms of textual structures and strategies, outlines the profile of the competent reader, the professional legacy does not tend to be weakened and more influenced by critical traditions focusing its attention exclusively on national literature but enlarges the observation to wider cultural contexts. In the opening of the education of teachers to the approach to a literary approach that invests competences of various nature (linguistic, reading, writing, communication, interpretive, discursive, cultural, cross-cultural, pragmatic and strategic and social), as well as of various types (cross-sectional, disciplinary etc.), the literary text provides not only the knowledge of life through its imaginary shape, but develops also a cohabitation, the cross-cultural one, which importance in the new system of the higher education cannot be underestimated. 


\section{Conclusion}

The literary competence and literature play a very wide role in the initial education of teachers, but are affected by a lacking research of empirical kind. The studies often comprise wide descriptions of experiences (Wragg, 1984), usually concerning future teachers under initial education who conversely approach literature almost exclusively from the point of view of narration and its pedagogical function (Batini \& Giusti, 2010) rather than in its role of "literary discourse" as concrete instrument of professionalization and socialization (Lacey, 1977) or critical theory (Ginsburg, 1988) leading to acquire higher-order skills such as the critical thinking and the reflective competence. This shows both epistemological and methodological weakness (Atkinson \& Delamont, 1985). The narration is perceived as instrument to explore thoughts, habits, and attitudes to express the knowledge and the job of teachers (Brown \& McIntyre, 1993; Schön, 1983). This is broadly "literary", and in the sense of "discourse" linked to the methodological dimension initiating a "new epistemology of practice” (Nuzzaci, 2012b) presented as opposition to an "empty formalization”. In this sense, the literary competence enters in the experiential processes of education of teachers as neglected element of processes of professionalization. But beyond the methodological variations above, there is a deep division between the experts on the concept of "literary nature" and teaching of literature. But, it is understood that, in the classes where teachers are educated, widespread and recent phenomenon, but qualifying the university context as privileged space for a critical glance at education and reality, literature opens to a certain number of knowledge and domains and helps the future teacher to build conceptual schemes that will need to develop a teaching based on:

(1) appropriate linguistic and communication domains and practices;

(2) elements of research in the field of the relationship between discourse and educational action;

(3) literary sources for personal and professional use and change;

(4) literary sources to activate specific forms of didactic transposition to specific disciplinary sectors;

(5) instruments of identification of reading, writing practices, etc.;

(6) methods to explain the schemes of knowledge behind the literary repertoires;

(7) innovative forms of evaluation of competences (area of production);

(8) domains (linguistic, pragmatic, cultural etc.) for disciplinary and cross-disciplinary contamination to define strategies of innovation;

(9) components and supports for methodological innovation and structuring;

(10) elements and starting points for a consideration on the use of literature in professional action and ethics.

Such a reasoning arises from the necessity to build a culture of learning and teaching of the literary competence as factor able to influence the set of competences of teachers of nursery school and primary school under initial education. In brief, the "literary reading" is thought to be part of a wider culture founding its roots in a wider repertoire producing some consequences of adjustment in teachers' life and their professional culture. Aware that until recent times the value of the literary reading in the education of teachers was mainly taken as a whole as communication experience, where the reader/teacher tends to re-contextualize or redefine some significant aspects of the experience by using a literary text to make effective the aspects leading the act of reading, there is the necessity to review this vision of literature in the light of more recent research lines. The changes of the last decades have given a boost to reshape the quality of education of teachers in Europe to 
provide the students future teachers with appropriate competences required by a school under transformation. The requirements of teachers of the nursery school and primary school are changing and the rapid social and technological development requires new knowledge and competences, and their contamination, which impose a further higher education and retraining. In order to assure the efficiency and effectiveness of the systems of education, the teachers, who put the basis of the structure and future knowledge, should be equipped with the capacity to give birth to a cultural project aiming at implementing the set of competences, knowledge, and experiences supplying a common theoretical, methodological, and practical base allowing teachers under initial training to promote appropriate alphabetical processes and active citizenship in their students. This is a long discourse, still open, on the concept of literary competence that has led to the elaboration of frameworks of competences as instruments aimed at defining, measuring, and evaluating the human literary performance according to various types of activity and well specific standards, intended to provide a definite reference:

(1) for those engaged in education of teachers when planning such education and preparing the fields of experience for an appropriate professional development;

(2) for teachers when they self-evaluate in order to better identify their requirements of professional development;

(3) for experts of the sector engaged in conceptualizing the competences linked to disciplinary didactics opening themselves to specific forms of planning and evaluation, such as, indeed, the literary one examined herein.

The assumption of such a competence in university paths concerning the education of teachers of nursery school and primary school becomes cause of deep change because interactions "mediated" by the student with the literary text produce either enhancement and understanding of many pedagogical experiences, or opening of future teachers to fanciful contexts where using language (Collie \& Slater, 1987; Gibbs, 1994), that may be turned into useful instruments from the didactic point of view and help to become familiar with specific styles of literacy and then encouraging its development (Krashen, 1985). The latter is an important component for the professional role that will be covered by the future teachers of nursery and primary schools, who may leverage on their literary competence to learn to teach to their future students the richness and variety of language and culture, to progressively build the knowledge of the language and its culturally determined meanings, so as to expand the understanding of one's own and other's cultures. In this interpretive key, the literature for the teachers under initial education can create both opportunities of personal expression and educational opportunities leading them to become teachers able to help their students to put the bases to progressively build their competence and examine in depth their knowledge concerning the lexical and grammatical structure (Savvidou, 2006) of the language, as well as understand the cultural meaning that it expresses, for it is not licit understand completely a language without understanding the cultural meanings conveyed by it (Lado, 1964, p. 9). Thus in the education of university students that are preparing themselves to become "teacher", the literary competence is acknowledged its own function, the same that Kramsch and Ricoeur (1976) connect to literature and concerning "production or non-reproduction of the discourse" or culture that is being represented and that the teacher will be able to teach only as long as making accessible and understandable for young students values, intentions and beliefs incorporated in various texts, transposing didactically the meanings expressed through the language, which meanings refer to culture and cultural experience with which the literature has been written and understood. The learning of the literary competence lives everywhere within the context of the education of teachers, in understanding educational goals to be pursued, as well as in teaching methods to be adopted, in 
approaches that resort to individualization and leverage on characteristics and personalities of students, in integration of technologies in didactic and methods to evaluate the quality of learning results. The strengthening of the "literary competence" within the set of competences of teachers is needed to make transparent the aspects connected to the improvement of the literary fruition and linguistic, textual production etc., or rather those areas that, ranging from childhood to adult age, passing through the history of the individual, in order to ensure the lifelong learning. The literary competence helps to be introduced in the didactic systems of action and of measurement of practical, innovative performances and forms of interactive communication, supporting the continuous passion for the profession of teacher and push it towards the research of those dimensions of “quality” making a teacher genuinely competent.

\section{References}

Ardissino, E. (a cura di). (2010). Leggere Poesia. 50 proposte didattiche per la scuola primaria (Poetry reading. 50 educational proposals for primary school). Trento: Erickson.

Ashworth, P., \& Saxton, J. (1990). On competence. Journal of Further and Higher Education, 14(2), 3-25.

Barrat-Pugh, L. (1995). The competence approach: Constricting development or the freedom to learn? A focus on learning (pp. 13-19). Proceedings from The $4^{\text {th }}$ Annual Teaching Learning Forum, Edith Cowan Univeristy. Retrieved from http://lsn.curtin.edu.au/tlf/tlf1995/barratt-pugh.html

Bassnett, S., \& Grundy, P. (1993). Language through literature. London: Longman.

Batini, F., \& Giusti, S. (a cura di). (2010). Imparare dalle narrazioni (Learning from narrations). Milano: Unicopli.

Belcher, D., \& Hirvela, A. (2000). Literature and L2 composition. Revisiting the debate. Journal of Second Language Writing, 9(1), 21-39.

Bertoz, A. (2015). La vicarianza. Il nostro cervello creatore di mondi (The vicariance. Our brain creator of worlds). Milano: BUR.

Bourdieu, P. (1988). La parola e il potere (The word and the power). Napoli: Guida.

Brown, S., \& McIntyre, D. (1993). Making sense of teaching. Buckingham: Open University Press.

Brumfit, C., \& Carter, S. (1986). Literature and language teaching. Oxford: Oxford University Press.

Calkins, L. M. (1994). The art of teaching writing. Portsmouth: Heinemann.

Cardarello, R. (1995). Libri e bambini. La prima formazione del lettore (Books and children. The first line of the reader). Firenze: La Nuova Italia.

Cardarello, R. (1997). Esperienze del testo nell'infanzia (Text experiences in childhood). In M. Vivarelli (Ed.), Il futuro della lettura (The future of reading) (pp. 113-128). Roma: Vecchiarelli.

Cardarello, R., \& Chiantera, A. (a cura di). (1989). Leggere prima di leggere (To read before reading). Firenze: La Nuova Italia.

Carter, R., \& Long, M. (1991). Teaching literature. Harlow: Longman.

Carter, R., \& McRae, J. (Eds.). (1996). Language, literature and the learner. London: Longman.

Carter, R., Walker, R., \& Brumfit, C. (1989). Literature and the learner: Methodological approaches. London: Modern English Publications and the British Council.

Causton-Theoharis, J. N., Theoharis, G. T., \& Trezek, B. J. (2008). Teaching pre-service teachers to design inclusive instruction: A lesson planning template. The International Journal of Inclusive Education, 12(4), 381-399.

Ceserani, R. (2010). Convergenze. Gli strumenti letterari e le altre discipline (Convergences. Literary tools and the other disciplines). Milano: B. Mondadori.

Chomsky, N. (1965). Aspects of the theory of syntax. Cambridge: MIT Press.

Cisotto, L. (2006). Didattica del testo. Processi e competenze (Didactic text. Processesand skills). Roma: Carocci.

Cisotto, L., \& Gruppo RDL Infanzia (2009). Prime competenze di letto-scrittura (Early reading and writing skills). Trento: Erickson.

Citton, Y. (2011). La competence lettéraire: Apprendre à (dè)jouer la maîtrise (Literary competence: Learning to full the mastery). Il Verri, 56(45), 32-41.

Coenen, L. (1992). Literaire competentie: werkbaar kader voor het literatuuronderwijs of nieuw containerbegrip? (Literary competence: Useful concept for literary education or new “catch-all term”?). Spiegel, 10(2), 55-78. 
Collie, J., \& Slater, S. (1987). Literature in the language classroom. Cambridge: Cambridge University Press.

Culler, J. (1975). Structuralist poetics: Structuralism, linguistics, and the study of literature. London: Routledge \& Kegan Paul.

Darling-Hammond, L. (1998). Investing in quality teaching: state-level strategies, 1999. Denver: Education Commission of the States.

Darling-Hammond, L., \& Richardson, N. (2009). Teacher learning: what matters? Educational Leadership, 66(55), 46-53.

Darling-Hammond, L., \& Youngs, P. (2002). Defining "Highly qualified teachers": What does "scientifically-based research" actually tell us? Educational Researcher, 31(9), 13-25.

Dewey, J. (1949). Democrazia e educazione (2016) (Democracy and education). Firenze: La Nuova Italia.

Dufay, J. L. (2007). Enseigner et apprendre la literature aujourd'hui, pour quoi faire? Sens, utilité, evaluation (Teaching and learning literature today, for what? Meaning, purpose, evaluation). Louvain: Presses Universitaires de Louvain.

Dufays, J. L., Gemenne, L., \& Ledur, D. $\left(2005^{2}\right)$. Pour une lecture littéraire. Histoire, théories, pistes pour la classe (For a literary reading. History, theories, tracks for class). Bruxelles: De Boeck.

Edmondson, W. (1997). The role of literature in foreign language learning and teaching: Some valid assumptions and invalid arguments. AILA Review, 6(12), 42-45.

Edwards, R., \& Nicoll, K. (2006). Expertise, competence and reflection in the rhetoric of professional development. British Educational Research Journal, 32(1), 115-131

Eraut, M. (1994). Developing professional knowledge. London: Falmer.

European Commission (June 2011). Literature review: Quality in teachers' continuing professional development. Author: Francesca Caena. Brussels.

European Commission. (2013 July 10). Supporting teacher competence development for better learning outcomes. European Commission Education and Training. Retrieved from http://ec.europa.eu/education/policy/school/doc/teachercomp_en.pdf

Fabbri, L. (2008). Nuove narrative professionali. La svolta riflessiva (New professional narrative. The turning thoughtful). In L. Fabbri, M. Striano, and C. Melacarne (Eds.), L'insegnante riflessivo. Coltivazione e trasformazione delle pratiche professionali (The thoughtful teacher. Cultivation and processing of professional practices) (pp. 15-66). Milano: FrancoAngeli.

Farber, G. (2005). What is literature? What is art? Integrating essence and history. Journal of Aesthetic Education, 39(3), 1-21.

Fish, S. (1980). Is there a text in this class? Cambridge, Mass.: Harvard University Press.

Gajdusek, L., \& van Dommelen, D. (1993). Literature and critical thinking in the composition classroom. In J. Carson and I. Leki (Eds.), Reading in the composition classroom: Second language perspectives (pp. 197-215). Boston: Heinle \& Heinle.

Gándara, P., Rumberger, R. W., Maxwell-Jolly, J., \& Callahan, R. (2003). English learners in California schools: Unequal resources, unequal outcomes. Educational Policy Analysis Archives, 11. Retrieved from http://epaa.asu.edu/epaa/v11n36/

Genovesi, G. (1993). Leggere oltre la scuola (Read beyond school). In G. Genovesi and P. Magri (a cura di), Leggere a scuola e oltre (Reading in school and beyond). Ferrara: Corso Editore.

Gibbs, R. W. (1994). The poetics of mind: Figurative thought, language, and understanding. New York: Cambridge University Press.

Gilroy, M., \& Parkinson, B. (1997). Teaching literature in a foreign language. Language Teaching, 29(4), 213-225.

Ginsburg, M. (1988). Contradictions in teacher education and society: A critical analysis. New York: Falmer Press.

Gower, R., \& Pearson, M. (1986). Reading literature. London: Longman.

Hagger, H., \& McIntyre, D. (2006). Learning teaching from teachers: Realising the potential of school-based teacher education. Maidenhead: Open University Press.

Haycock, K. (1998). Good teaching matters. Washington: Education Trust.

Hirsch, E., Koppich, J. E., \& Knapp, M. S. (1998). What states are doing to improve the quality of teaching. A brief review of current patterns and trends. Seattle: The Center for the Study of Teaching and Policy, University of Washington.

Hodkinson, P., \& Issitt, M. (1995). The challenge of competence. London: Cassell.

Ibsch, E., Schram, D., \& Steen, G. (Eds.) (1991). Empirical studies of literature. Proceedings of the Second IGEL-Conference, Amsterdam 1989. Amsterdam \& Atlanta: Rodopi.

Isenberg, N. (1990). Literary competence: The EFL reader and the role of the teacher. ELT Journal, 44(3), 182-190.

Jakobson, R. (1988). The metaphoric and metonymic poles. In D. Lodge (Ed.), Modern criticism and theory. A reader (pp. 57-61). London: Longman.

Janssen, T. (1996). Asking for trouble. Teacher questions and assignments in the literature classroom. SPIEL: Siegener Periodicum zur Internationalen Empirischen Literaturwissenschaft, 15(1), 8-23. 
Janssen, T., \& Rijlaarsdam, G. (1990). What pupils learn from literature teaching in the Netherlands. In M. Hayhoe and S. Parker, Reading and response (pp. 94-106). Milton-Keynes-Philadelphia: Open University Press.

Janssen, T., \& Rijlaarsdam, G. (1996). Approaches to the teaching of literature: A national survey of literary education in Dutch secondary schools. In R. J. Kreuz and M. S. MacNealy (Eds.), Empirical approaches to literature and aesthetics (Vol. 52 in the Series Advances in Discourse Processes, pp. 513-536). Norwood, New Jersey: Ablex Publishing Corporation.

Janssen, T., \& Rijlaarsdam, G. (1996). Students as self-assessors: Learning experiences of literature teaching in secondary schools. In E. Marum (Ed.), Children and books in the modern world: contemporary perspectives on Literacy (pp. 98-115). London: The Falmer Press.

Kerlinger, F. N. $\left(1973^{2}\right)$. Foundations of behavioral research. New York: Holt, Rinehart and Winston, Inc.

Keunen, B., \& Eeckhouf, B. (Eds.). (2001). Literature and society. Lang: Bruxelles.

Kim, M. (2004). Literature discussions in adult L2 learning. Language and Education, 18(2), 145-166.

Kramsch, C. (1993). Context and culture in language teaching. Oxford: Oxford University Press.

Lacey, C. (1977). The socialisation of teachers. London: Methuen.

Lado, R. (1964). Language teaching: A scientific approach. New York: McGraw-Hill.

Lazar, G. (1993). Literature and language teaching. Cambridge: Cambridge University Press.

Lee, Y. A., \& Hemer-Patnode, L. (2010). Developing teacher candidates' knowledge, skills, and dispositions to teach diverse students. Journal of Instructional Psychology, 37(34), 223-224.

Livolsi, M. (a cura di). (1986). Almeno un libro. (At least a book). Firenze: La Nuova Italia.

Lumbelli, L. (a cura di). (1988). Incoraggiare a leggere (Encouraging reading). Firenze: La Nuova Italia.

Lumbelli, L., \& Salvadori, M. (1977). Capire le storie, un modo di usare i racconti illustrati nella scuola dell'infanzia (Understand the stories, a way of using the illustrated tales in kindergarten). Milano: Emme Edizioni.

Lyas, C. (1997). Aesthetics. London: UCL Press.

Maley, A. (1989a). Down from the pedestal: Literature as resource. In R. Carter, R. Walker, and C. Brumfit (Eds.), Literature and the learner: Methodological approaches (pp. 1-9). London: Modern English Publications and the British Council.

Maley, A. (1989b). A comeback for literature? Practical English Teacher, 10, 59.

Maley, A., \& Duff, A. (1989). The inward ear: Poetry in the language classroom. Cambridge: Cambridge University Press.

Margiotta, U. (1999). L'insegnante di qualità. Valutazione e performance (The quality teacher. Assessment and performance). Roma: Armando.

Nuzzaci, A. (1999). La competenza nella riflessione pedagogica. Scuola democratica, 22(1/2), 214-243.

Nuzzaci, A. (2004). Profili di competenza e trasformazioni sociali. Insegnare e apprendere (Skill profiles and social transformations. Teaching and learning). Cosenza: Lionello Giordano Editore (seconda edizione rivista e aggiornata 2010).

Nuzzaci, A. (2012a). The "Technological good" in the multiliteracies processes of teachers and Students. International Journal of Digital Literacy and Digital Competence, 3(3), 12-26.

Nuzzaci, A. (2012b). Competenze, processi regolativi e riflessivi (Competences, regulatory and reflexive processes). Brescia-Lecce: Pensa MultiMedia Editore s.r.l.

Nuzzaci, A. (2014, December). ICT, Educational design e formazione iniziale e continua degli insegnanti (ICT, educational design and initial and continued teacher training) (2nd December 2014, Department of Human Studies, University of L'Aquila).

OCSE-PISA. (2009). Retrieved from http://www.invalsi.it/invalsi/ri/pisa2009.php?page=pisa2009_it_01b

OECD (Organisation for Economic Co-operation and Development). (2005). The definition and selection of key competencies. Retrieved from https://www.pisa.oecd.org/dataoecd/47/61/35070367.pdf

Parkinson, B., \& Reid Thomas, H. (2000). Teaching literature in a second language. Edinburgh: Edinburgh University Press.

Poyas, Y. (2004). Exploring the horizons of the literature classroom; reader response, reception theories and classroom discourse. L1-Educational Studies in Language and Literature, 4(1), 63-84.

Reuchlin, M. (1978). Processus vicariants et differences individuelles (Vicarious processes and individual differences). Journal de Psychologie, 2, 133-145.

Reuchlin, M. (1999). L'évolution de la psychologie différentielle (The evolution of differential psychology). Paris: Presses Universitaires de France.

Rijlaarsdam, G., \& Janssen, T. (1996). How do we evaluate the literature curriculum? About a social frame of reference. In E. Marum (Ed.), Children and books in the modern world: Contemporary perspectives on literacy (pp. 75-98). London: The Falmer Press. 
Rosenblatt, L. (1938). Literature as exploration. New York: D. Appleton-Century.

Rouxel, A. (1996). Enseigner la lecture littéraire (Teaching the literary reading). Rennes: Presses Universitaires de Rennes.

Sánchez, P. (2008). The use of literature with different language levels. English Text Construction, 1(2), 226-238.

Savvidou, Ch. (2004). An integrated approach to teaching literature in the EFL classroom. The Internet TESL Journal, 12(11). Retrieved from http://iteslj.org/Techniques/Savvidou-Literature.html

Schmidt, S. (1982). Foundations for the empirical study of literature: The components of a basic theory. (R, de Beaugrande, Trans.). Hamburg: Buske.

Schön, D. (1983). The reflective practitioner: How professionals think in action. New York: Basic Books.

Shulman, L. (1986). Paradigms and research programs in the study of teaching: A contemporary perspective. In M. Wittrock (Ed.), Handbook of research on teaching (pp. 3-36). New York: London: MacMillan.

Shulman, L. S. (1987). Knowledge and teaching: Foundations of the new reform. Harvard Educational Review, 14(5), 1-22.

Soetaert, R. (1992). Literairecompetentie, eenbegrip van betekenis (Literary competence, a concept of importance). In W. de Moor and M. van Woerkom (Eds.), Neem en lees. Literaire competentie. Het doel van het literatuuronderwijs (Take and read. Literary competence. The aim of literary education) (pp. 33-45). Den Haag: NBLC.

Soetaert, R., \& A. Mottart (2003). Teaching literature. Confronting repertoires. Symposium on Reading \& Interpreting Literary Texts. Presented at the IAIMTE's Fourth International Conference on Learning and Teaching of Language and Literature.

Stewart, J., \& Hamlin, B. (1995). Competency-based qualifications: The case for established methodologies. Journal of European Industrial Training, 6(10), 9-16.

Tonelli, N. (a cura di) (2013). Per una letteratura delle competenze. I Quaderni della Ricerca (Fora competences literature. Research Series). Torino: Loescher.

Trerè, S., \& Gallegati, G. (1995). Strumenti per un'analisi testuale (Tools for a textual analysis). Firenze: Bulgarini.

Usher, R., \& Edwards, R. (1994). Postmodernism and education. London: Routledge.

Van Schooten, E. J. (2005). Literary response and attitude toward reading fiction. Academic thesis. Groningen: University of Groningen. Retrieved from http://11.publicationarchive.com/start

Vandrick, S. (2003). Literature in the teaching of second language composition. In B. Kroll (Ed.), Exploring the dynamics of second language writing (pp. 263-283). Cambridge: CUP.

Velde, C. (1999). An alternative conception of competence: implications for vocational education. Journal of Vocational Education and Training, 51(3), 437-447.

Verboord, M. (2005). Long-term effects of literary education on book-reading frequency; an analysis of Dutch student cohorts 1975-1998. Poetics, 33(5-6), 320-342.

Widdowson, H. G. (1990). Stylistics and the teaching of literature. Oxford: Oxford University Press.

Wragg, E. C. (Ed.) (1984). Classroom teaching skills. London: Croom Helm.

Yang, A. (2001). Reading and the non-academic learner: A mystery solved. System, 29(4), 451-466. 